\title{
Optimization of maggot production from a mixture of chicken viscera and soya cake based on different ratios
}

\author{
N. Isidore ODJO*, S. M. Arnauld DJISSOU, Chimène GUEZO and \\ D. Emile FIOGBE
}
Faculty of Sciences and Technology/Laboratory of Research on Wetlands (LRZH)/ University of Abomey- Calavi (UAC), Benin.
*Corresponding author; E-mail: odjoisidore@gmail.com

\begin{abstract}
In order to promote new local protein sources to fish feed, a study based on maggot production from a mixture of chicken viscera and soya cake was carried out in the station of research on fish farming diversification of the University of Abomey-Calavi (Benin) to determine the proportions of substrates combination that can provide the best productivity of maggot. Five treatments ( $\mathrm{T}_{1}$ to $\mathrm{T}_{5}$ ) made of chicken viscera $(\mathrm{CV})$ and soya cake (SC) with different ratios served to produce maggot. Ratios $1: 1 ; 2: 1 ; 1: 2 ; 1: 3$ and 3:1 among chicken viscera and soya cake were used to constitute respectively treatments $T_{1}, T_{2}, T_{3}, T_{4}$ and $T_{5}$. Resulting from the experiment, the density of production varies significantly at the level according to ratios of the different treatments. The temperature values $\left(28.2 \pm 0.6{ }^{\circ} \mathrm{C}\right)$ and the relative humidity $(96 \pm 2 \%)$ recorded show that they comply with the requirements to maggot development of maximum production. The mean productivity varied between 660 and 1250 according to the ratio of the different treatments. The best production densities of maggot such as 13.89 and $11.67 \mathrm{~g} / 100 \mathrm{~g}$ are respectively obtained with ratios $2: 1$ and 1:3 between CV and SC. This density of production is according of the nature but especially of the proportion of chicken viscera and soya cake in the mixture. Mean heights increased when the proportion of SC is high and the individual mean weight remained high when the proportion of $\mathrm{CV}$ in the mixture is higher or equals to those of SC.
\end{abstract}

(C) 2018 International Formulae Group. All rights reserved.

Keywords: Production, production density, maggot, productivity.

\section{INTRODUCTION}

In Benin, the supply of aquatic resources is continuously difficult. This situation is the result of an irrational exploitation of these resources that leads to a serious decrease of aquatic products by booking place to small heights species and the scarcity of big species like Clarias gariepinus, Heterobranchus longifilis, Heterotis niloticus, etc. (Imorou, 2007). To solve this difficulty, fish farming constitute the solution to provide animal genuine proteins to the population (PROVAC, 2013). But this latter encounters some problems such as feeding. Indeed, feed represents the important part of production cost (Aniebo et al., 2009), and limit the economical interest of aquaculture (Fiogbé et al., 2004, Djissou et al., 2015). This high cost can be justified by the use of fish meal and oil that are rich in nutrients such as essential amino acids and poly unsaturated fat (Anvo et al., 
2017; Djissou, 2017) and which profile is in accordance with the nutritional needs of fish.

Fish meal is the reason of the high price of feed (Bamba et al., 2008) due to its richness in essential amino acids. Some agricultural byproducts are increasingly used as source of proteins in fish feed (Azaza et al., 2006; Abarike et al., 2013). The use of these sources of proteins has already provided good results (Nyawamziza, 2007; Médale et al., 2013; Djissou et al., 2016).

So the valorization of food wastes to provide animal genuine proteins sources (maggot, earth worm, termites, etc.) constitute a real alternative not only to fish meal substitution but to the production cost of fish feed. During the latter years, many studies revealed the efficiency of several substrates in the production of maggot (Ekoue and Hadzi, 2000; Mpoame et al., 2004; Bouafou et al., 2007). The productivity of these substrates varies as a function of their nature (Djissou et al., 2015) but any study was not carried out to determine the impact of substrates proportions used in mixture.

The aim of this study was to produce maggot from chicken viscera and soya cake and to determine the proportions of substrates combination that could help to obtain the best productivity of maggot.

\section{MATERIAL AND METHODS}

The experiment was carried out on the station of research on fish farming diversification of the University of AbomeyCalavi for five (05) days, because the mean cycle of maggot production is five (05) days. Basing on the results of Djissou et al. (2015), a substrate made of chicken viscera and soya cake (with different ratios) served to constitute five (05) treatments of maggot production. To ascertain the ratio can give the best productivity of maggots, ratios of $1: 1, ; 2: 1 ; 1: 2$ ; 1:3 and 3:1 between chicken viscera and soya cake were respectively chosen (Table 1). Chicken viscera are from markets of chicken slaughtering and soya cake from soybean transformation units. Four kilograms $(4 \mathrm{~kg})$ of substrate, in combined proportions, were seeded in plastic glass containers replicated three (03) times. The treatments were set under a shed to prevent them from sun rays and rain.

The morning of the first day, every container is filled of $4 \mathrm{Kg}$ of substratum (weighed with a spring balance) and let to aérage of air sprinkled him slightly then of water every evening until the harvest of maggots. Harvest began from the $4^{\text {th }}$ to the $5^{\text {th }}$ day after experiment start up without renewing or supplying of substrate. It was carried out all the time by pouring the substrate on a net under which a bowl was set in order to collect maggot.

\section{Temperature and humidity}

The temperature and humidity of the air were measured at 8 am and $4 \mathrm{pm}$ everyday respectively with a thermo-hygrometer Extech, model MO210. These values varied respectively from 27.5 to $28.9^{\circ} \mathrm{C}$ and from 93 to $96 \%$ of relative humidity.

\section{Productivity}

Maggot counting was carried out according to the method of Ekoue and Hadzi (2000). Maggot weighting was done by using a balance of precision $0.001 \mathrm{~g}$ and $1000 \mathrm{~g}$ carrying capacity. The parameters measured include productivity or total biomass, height, individual weight and production density of maggot per $1000 \mathrm{~g}$ of substrate. Hundred (100) maggots were sampled per treatment and then weighted to determine their individual weight. Other fifty (50) maggots were sampled per 
treatment, spread on a pallet and heights were determined with a graduated ruler.

Maggot mean weight (g)

$=\frac{\text { Total maggots quantity }}{\text { Total maggots Number }}$

Production density $(\mathrm{d})(\mathrm{g} / 100 \mathrm{~g}$ of substrate $)=$ Total maggots quantity

Totale substrate quantity

\section{Statistical analyses}

Data obtained from the experiment were subjected to one-way analysis of variance after verifying the normality and the homogeneity of variance using the statistical software Statviews (version 5.01). Least-significantdifference test of Fisher was used to compare differences among individual means. Treatment effects were considered significant at $\mathrm{P}<0.05$.

Table 1: Nature and substrate composition.

\begin{tabular}{|c|c|c|c|}
\hline Substrate & Treatment & Composition (Kg) & Ratio \\
\hline \multirow{5}{*}{$\begin{array}{l}\text { Chicken viscera }(\mathrm{CV})+ \\
\text { Soya cake (SC) }\end{array}$} & T1 & $2(\mathrm{CV})+2(\mathrm{SC})$ & $1: 1$ \\
\hline & $\mathrm{T} 2$ & $2.67(\mathrm{CV})+1.33(\mathrm{SC})$ & $2: 1$ \\
\hline & $\mathrm{T} 3$ & $1.33(\mathrm{CV})+2.67(\mathrm{SC})$ & $1: 2$ \\
\hline & $\mathrm{T} 4$ & $1(\mathrm{CV})+3(\mathrm{SC})$ & $1: 3$ \\
\hline & $\mathrm{T} 5$ & $3(\mathrm{CV})+1(\mathrm{SC})$ & $3: 1$ \\
\hline
\end{tabular}

\section{RESULTS}

The values of the temperature and the relative humidity recorded during this experiment varies respectively from 27.6 to $28.8{ }^{\circ} \mathrm{C}$ and 94 to $98 \%$ between the treatments.

Table 2 presented the mean productivity of maggots from different treatments. The mean productivity varied according to the different ratios between substrates. It varies from $660 \mathrm{~g}$ to $1250 \mathrm{~g}$ according to different ratios between substrates at level of treatments ( $T_{1}$ to $T_{5}$ ). Productivities varied significantly from a treatment to another $(\mathrm{P}<0.05)$ with the best productivity obtained in treatment $\mathrm{T}_{2}$ (ratio 2:1 between chicken viscera and soya cake).
There were no significant differences among the individual mean weights contrary to mean heights $(\mathrm{P}<0.05)$. Mean heights increased when the proportion of SC is high. Individual mean weight remained high when the proportion of $\mathrm{CV}$ in the mixture is higher or equals to those of SC (Figure 1). The production density varied significantly as a function of ratios in the different treatments. The best production densities were obtained in treatments $\mathrm{T} 2$ and $\mathrm{T} 4$ (Figure 2) respectively with ratios 2:1 and 1:3 between CV and SC. This density is function of the nature but especially the proportion of chicken viscera and soya cake in the mixture. 
Table 2: Maggots productivity from different treatments.

\begin{tabular}{|c|c|c|c|c|c|c|}
\hline \multicolumn{2}{|c|}{ Treatments } & \multirow{2}{*}{$\begin{array}{l}\text { T1 } \\
830 \pm 30^{\mathrm{a}}\end{array}$} & \multirow{2}{*}{$\begin{array}{c}\mathbf{T 2} \\
1250 \pm 48^{\mathrm{b}}\end{array}$} & \multirow{2}{*}{$\begin{array}{c}\mathbf{T 3} \\
660 \pm 8^{c}\end{array}$} & \multirow{2}{*}{$\begin{array}{c}\mathbf{T 4} \\
1050 \pm 10^{\mathrm{d}}\end{array}$} & \multirow{2}{*}{$\begin{array}{c}\text { T5 } \\
750 \pm 15^{\text {ac }}\end{array}$} \\
\hline Total & Quantity (g) & & & & & \\
\hline & $\begin{array}{l}\text { Maggots } \\
\text { number }\end{array}$ & $16593 \pm 14$ & $25001 \pm 46$ & $16429 \pm 21$ & $26261 \pm 32$ & $15037 \pm 17$ \\
\hline \multirow[t]{2}{*}{ Sample } & $\begin{array}{l}\text { Mean height } \\
(\mathrm{cm})\end{array}$ & $1.4 \pm 0.08^{\mathrm{ab}}$ & $1.2 \pm 0.04^{\mathrm{a}}$ & $1.5 \pm 0.08^{b}$ & $1.6 \pm 0.06^{\mathrm{b}}$ & $1.1 \pm 0.06^{\mathrm{a}}$ \\
\hline & $\begin{array}{c}\text { Maggot } \\
\text { mean } \\
\text { weight }(\mathrm{g})\end{array}$ & $0.05 \pm 0.01$ & $0.05 \pm 0.01$ & $0.04 \pm 0.01$ & $0.04 \pm 0.01$ & $0.05 \pm 0.01$ \\
\hline \multicolumn{2}{|c|}{$\begin{array}{l}\text { Production density } \\
\text { (g/100g of substrate) }\end{array}$} & $9.22 \pm 0.48^{\mathrm{a}}$ & $13.89 \pm 0.46^{\mathrm{b}}$ & $7.33 \pm 0.54^{\mathrm{a}}$ & $11.67 \pm 0.18^{b}$ & $8.33 \pm 0.06^{\mathrm{a}}$ \\
\hline
\end{tabular}

Mean \pm SD values in the same line followed by the same superscript are not significantly different $(\mathrm{P}>0.05)$.

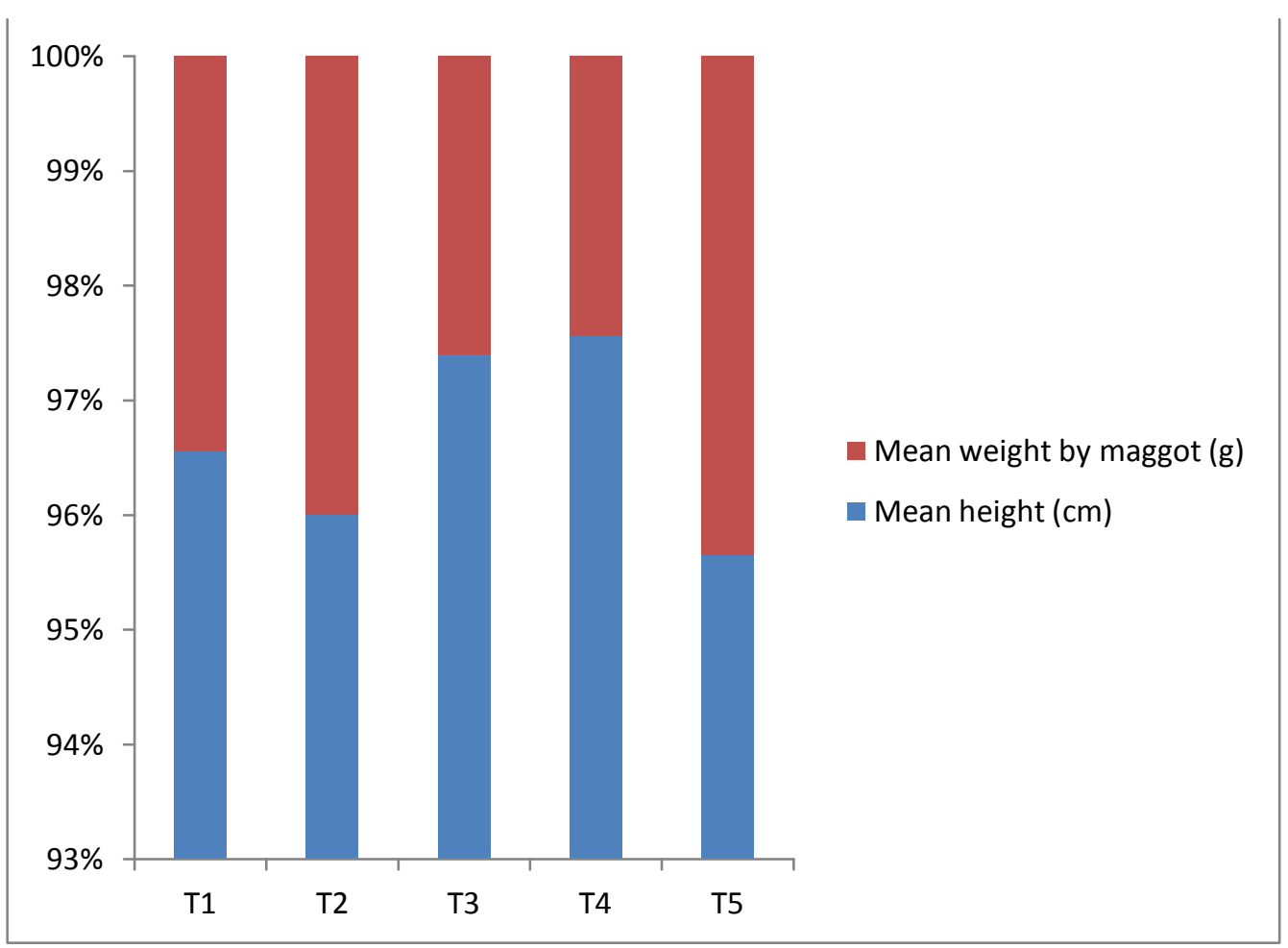

Figure 1: Progression of the mean weight and height of maggots according to treatments. 


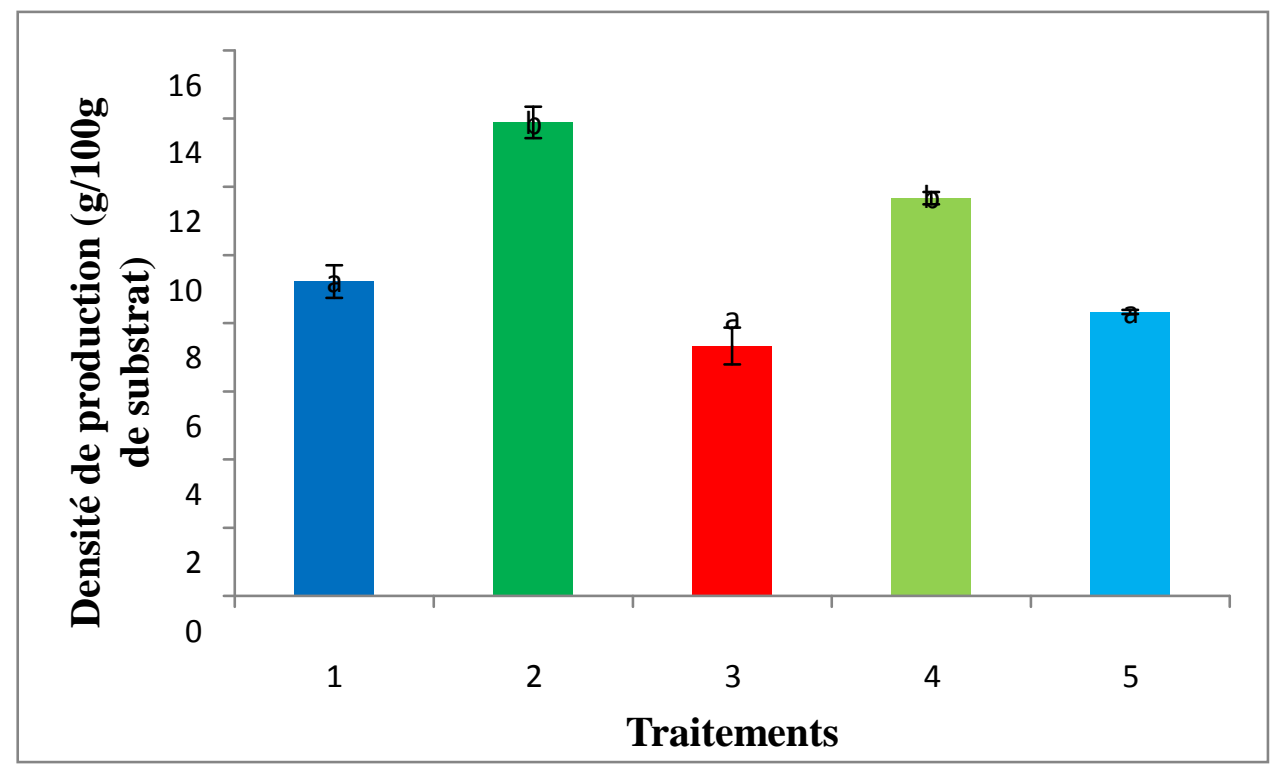

Figure 2: density of Production (g/100g of substrate) of maggots by treatment.

\section{DISCUSSION}

Temperature value $28.2 \pm 0.6{ }^{\circ} \mathrm{C}$ recorded during the experiment show that they are suitable to maggot development for a maximum production (Bouafou, 2011). To grow, maggot requires a high humidity rate. Relative humidity recorded during the experiment is $96 \pm 2 \%$, which is closed to $97 \%$ necessary to maggot development (Nzamujo, 1999; Djissou et al. 2015).

In the whole of the results obtained, the mean productivity of the maggots strongly varies according to the relationship between the chicken viscera and the soya bean cake. These results indicate that the mean weight of the maggots is high when the proportion of incorporation of the chicken viscera in the substrate of production is higher or equal to that of the soya bean cake. But the size of the maggots increases with the proportion of the soya bean cake in the mixture. Also, the quantities, the number of maggots just as the density of production are strongly correlated with the relationship between the chicken viscera and the soya bean cake in the substrates of production.

Maggots productivity obtained at level the treatments were on the one hand, better comparatively to those obtained by Ekoue and
Hadzi (2000) who used the content of cow rumen and on the other hand, Bouafou (2007) who used yam peeling and raw piece of yam, raw peeling of ripe banana and fresh fish waste and raw rat meat for maggot production on. These results were also best that those recorded by Djissou et al. (2015) who used pig dung, chicken viscera and soya cake to produce maggot. Results from Tendonkeng et al. (2017) on maggot production based on rumen content, pig dung, their mixture and each of these substrates with $10 \%$ of fresh goat blood, provided maggots which individual mean weight varied from 7.3 to $25.4 \mathrm{mg}$. These results are lower than those recorded among treatments during this experiment.

The production difference observed in the different treatments despite the identical nature of substrates can be explained by the organic matter quality and fly attraction by the substrates due to their odor. Indeed, a mixture of animal wastes origin and vegetable has a significant attractive potential on the flies from their color, their texture and of the odors which it releases (Bouafou, 2011). This assertion is justified by the high proteins rate and essential amino acids composition of chicken viscera (Hèdji et al., 2014; Djissou et al., 2017) and soya cake (Djissou et al., 2015). In addition, the 
excellent composition of chicken viscera in proteins and amino acids compared with soya cake on the one hand, the color and texture of the substrate on the other hand, explain the best productivity recorded in $\mathrm{T} 2$ (ratio 2:1 between CV and SC). The development of the maggots depends on the availability in the substrates of the matters nitrogenized and phosphored necessary for the decomposition (Djissou et al. 2015). Our results showed that a better productivity when the chicken viscera dominate in the mixture. This confirms work of Bouaffou (2011) who asserted that the productivity of maggots was weak with vegetable substrates (these substrates are not rich in proteins). These results are justified by the nature of the substrate used but also by the technique of production unfavorable to the deposit of the flies.

These results confirm those recorded by Djissou et al. (2015) who showed that chicken viscera and soya cake used in mixture constitute the best substrates for maggot production. As a result, the density of production obtained depends not only on ecological conditions, the production season, the nature of the substrate, the production technology but on the substrate quality (mixture of animal and vegetal genuine substrate) and on the mixture ratio particularly.

The present study shows that for the best production, a mean weight and density of maggot production were obtained with the mixture of chicken viscera and soya cake when the ratio $2: 1$ between these substrates is used. The production density of maggots is function of the substrate quality, its composition and the ratio between mixed substrates.

\section{COMPETING INTERESTS}

The authors declare that they have no competing interests.

\section{AUTHORS CONTRIBUTIONS}

IO: Control of the experiment, Statistical analyzes, Drafting of article;
AD: Amino acids and biochemical composition of animal proteins sources analyzes, Reading drafting article; CG: Control of the experiment, Drafting of article; EF: Supervision of the experiment, Reading drafting article.

\section{REFERENCES}

Abarike ED, Edward AO, Attipoe FYK. 2013.

Growth and economic performance of fingerlings of Oreochromis niloticus fed on different non-conventional feeds in out-door hapas at Akosombo in Ghana. African Journal of Agricultural Research, 8(26): 3384-3391.

DOI:10.5897/AJAR12.593.

Aniebo AO, Erondu ES, Owen OJ. 2009. Replacement of fish meal with maggot meal in African catfish (Clarias gariepinus) diets. Revista UDO Agricola 9(3): 666-671. http://www.bioline.org.br/abstract;id=cg 09081.

Azaza MS, Mensi F, Imorou TI, Dhraief MN, Abdelmouleh A, Brini B, Kraïem MM. 2006. Effets de l'incorporation de la farine de tomate dans l'alimentation du tilapia du Nil (Oreochromis niloticus L., 1758) en élevage dans les eaux géothermales du sud tunisien. Bulletin de l'Institut National des Sciences et Technologies, Mer de Salammbô, 33: 4152.

Bamba Y, Allassane O, Da Costa KS, Gourène G. 2008. Production d'Oreochromis niloticus avec des aliments à base de sous-produits agricoles. Sciences \& Nature, $\quad 5$ (1): $\quad 89-99$.

http:/www.afriquescience.info/doc.php ; id $=5235$.

Bouafou KGM. 2007. Etude de la production d'asticots à partir d'ordures ménagères et de la valeur nutritionnelle de la farine d'asticots séchés (FAS) chez le rat en croissance [thèse]. Abidjan Université de Cocody, 145. pp. 
Bouafou KGM. 2011. Revue bibliographique sur les asticots et leur emploi dans l'alimentation animale. Journal of Animal \& Plant Sciences, 12(2): 1543-1551. http://www.biosciences.elewa.org/JAPS.

Djissou ASM, Ochiai A, Koshio S, Fiogbé ED. 2017. Effect of total replacement of fishmeal by earthworm and Azolla filiculoides meals in the diets of Nile tilapia Oreochromis niloticus (Linnaeus, 1758) reared in concrete tanks. Indian Journal of Fisheries, 64(1): 31-36. DOI: 10.21077/ijf.2017.64.1.55317-05.

Djissou ASM, Tossavi CE, Vodounnou DSJV, Toguyeni A, Fiogbé ED. 2015. Valorization of agro-alimentary waste for a production of maggots like source of proteins in the animal feed. International Journal of Agronomy and Agricultural Research, 7(6): 42-46.

http://www.innspub.net.

Ekoue SE, Hadzi YA (2000). Production d'asticots comme source de protéines pour jeunes volailles au TogoObservations préliminaires. Notes Techniques. Tropicultura, 18(4): 212214.

Fiogbé ED, Micha J-C, Van Hove C. 2004. Use of a natural aquatic fern, Azolla microphylla, as a main component in food for Omnivorous-phytoplanktonophagous tilapia, Oreochromis niloticus L. Journal of Applied Ichthyology, 20: 517-520. DOI:10.1111/j.1439-0426.2004.00562.x

Hedji CC, Houinato M, Yehouenou B, Fiogbe ED. 2014a. Effect of packaging on the microbiological quality of chicken and fish viscera flour. International Journal of Current Microbiology and Applied Sciences, $\quad 3(10): \quad 233-242$. http://ijmcr.com.
Imorou TI. 2007. Amélioration de la production halieutique des trous traditionnels à poissons (whedos) du delta de l'Ouémé (sud Bénin) par la promotion de l'élevage des poissons-chats Clarias gariepinus et Heterobranchus longifilis. Thèse de Doctorat. Facultés Universitaires Notre-Dame de la Paix (FUNDP-Namur), p. 214.

Médale F, Le Boucher R, Dupont-Nivet M, Quillet E, Aubin J, Anserat J. 2013. Des aliments à base de végétaux pour les poissons d'élevage. INRA Production Animale, 26(4): 303-316.

Mpoame, Téguia A, Nguemfo EL. 2004. Essai comparé de production d'asticots dans les fientes de poule et dans la bouse de vache. Tropicultura, 22(2): 84-87. www.tropicultura.org/content/2004 vol. $22 \mathrm{n}^{\circ} 2 \mathrm{html}$.

Nzamujo OP. 1999. Technique for maggot production. The Songhai experience. 8pp. Unpublished.

PROVAC. 2013. Elevage de poissons en étang au Bénin. Préparé et publié à la Direction de la production Halieutique par le projet de Vulgarisation de l'Aquaculture Continentale en République du Bénin, JICA/MAEP. Cotonou, p. 21.

Tendonkeng F, Miégoué E, Lemoufouet J, mouchili M, Matimuini NF, Mboko AV, Fogang Zogang B, Mweugang NN, Zougou TG, Boukila B, Pamo TE (2017). Production et composition chimique des asticots en fonction du type de substrat. Livestock Research for Rural Development, 29 http://www.lrrd.org/lrrd29/4/ften29067.h tml. 